\title{
Фармакоекономічна оцінка альтернативних методів лікування виразкової хвороби шлунка
}

\author{
I. YA. DZUBANOVSKYI, L. YE. VIYTOVYCH, O. V. TRYHUBCHAK \\ SHEI "Ternopil State Medical University by I. Ya. Horbachevsky"
}

\author{
PHARMACOECONOMIC EVALUATION OF ALTERNATIVE METHODS OF TREATMENT OF GASTRIC \\ ULCER
}

\begin{abstract}
У роботі проведено порівняльну оцінку резекційних та органозберігаючих операційних втручань, а також консервативного лікування виразкової хвороби шлунка фармакоекономічним методом “витрати-корисність”. Загострено увагу на наявності даної патології в більшості осіб працездатного віку від 20 до 59 років у 49 \% випадків, що вказує на соціальне значення даної проблеми. Дані результати анкетного опитування хворих на виразкову хворобу шлунка спрямовані на оцінку якості життя пацієнтів, пов'язану зі станом здоров'я. Розраховано витрати на кожен із методів лікування. Враховано кількість медперсоналу, задіяного в операції залежно від виду операції, оплату його праці, витратні матеріали при виконанні операцій, середні витрати на перев'язки у післяопераційному періоді, середню вартість післяопераційного медикаментозного забезпечення, витрати на лікарські препарати, які входять до схеми послідовної терапії виразкової хвороби. Враховано частоту загострень виразкової хвороби шлунка та можливість виникнення післяопераційних ускладнень. Виражено корисність у кількісному значенні показника QALY, враховуючи тривалість подовженого життя хворих після досліджуваних методів лікування та якість їхнього життя. Обцрунтовано переваги органощадних операційних втручань $з$ фармакоекономічної точки зору.
\end{abstract}

A comparative evaluation of resecting and organsaving surgery and conservative treatment of gastric ulcer was held by the pharmacoeconomical method of "cost-utility". The attention was pointed to the presence of this disease in the majority of people of working age from 20 to 59 years, in $49 \%$ of cases, indicating the social importance of this problem. The results of a questionnaire survey of patients with peptic ulcer of the stomach, aiming at the assessment of the quality of life of patients were associated with the condition. There were estimated costs to each method of treatment. Authors took into account the number of staff involved in the operation depending on the type of operation, labor, consumables during operations, the average cost of dressings in the postoperative period, the average cost of post-operative medical support, the cost of medicines included in the scheme sequential treatment of peptic ulcer disease. The frequency of exacerbation of peptic ulcer of the stomach and the possibility of postoperative complications was recorded. The usefulness in the quantitative value of the indicator QALY, was expressed the elongated life expectancy of patients after the studied methods of treatment and their quality of life was given. The advantages of organsaving surgical interventions from the pharmacoeconomic point of view were grounded.

Постановка проблеми і аналіз останніх досліджень та публікацій. В останні роки зріс інтерес до проблем економічної оцінки ефективності лікування різних захворювань, що зумовлено появою альтернативних методів терапії, великої кількості нових дорогих медичних технологій, лікарських препаратів, підвищенням вартості медичних послуг, а також відносною обмеженістю грошових коштів, що виділяються на охорону здоров'я [1]. Враховуючи безперервні дискусії навколо вибору оптимальної тактики лікування виразкової хвороби шлунка (ВХШ) [2, 3], фармакоекономічний аналіз може стати вагомим аргументом на користь того чи іншого методу. Використання фармакоекономічного методу “вартість-корисність” (cost- utility) [4] дозволяє за допомогою показника корисності, встановленого на основі суб'єктивної оцінки хворими якості життя (ЯЖ), аналізувати альтернативні схеми лікування. Слід зазначити, що в хірургічній гастроентерології лікарі, як правило, основну увагу приділяють тривалості життя. При цьому зазвичай випускають із уваги, що для конкретного пацієнта має істотно більше значення не тільки динаміка симптомів захворювання, а й поліпшення самопочуття й підвищення задоволення життям у фізичному, психоемоційному та соціальному аспектах [5].

Мета роботи: провести фармакоекономічну оцінку альтернативних методів лікування ВХШ для вибору оптимальної тактики лікування не ли- 
ше за медичними показаннями, а й з урахуванням інших аспектів життя пацієнта.

Матеріали і методи. В основу даної роботи покладено результати обстеження та лікування 168 хворих із виразковою хворобою шлунка, які перебували на стаціонарному лікуванні у хірургічному відділенні КЗ ТОР “Тернопільська університетська лікарня” та в Тернопільській міській клінічній лікарні (ТМКЛ) № 2. Проведено порівняльну оцінку ефективності різних методів операційного й консервативного лікування ВХШ. Використано фармакоекономічний метод “вартістькорисність”. Це форма аналізу, при якій особливу увагу приділено зміні ЯЖ хворого, якому призначають ту чи іншу програму лікування. При цьому показник користі як ефективність лікування при використанні альтернативних схем аналізували на основі оцінки ЯЖ хворих (фізичного, психічного, соціального благополуччя), визначеної за опитувальником MOS SF-36, та скорегованої за кількістю років життя, стандартизованих за якістю з обчисленням індексу QALY [6]. Вибір оптимального методу лікування визначається коефіцієнтом “витрати-корисність”, який обчислюється часткою витрат і показника корисності. Даний коефіцієнт показує величину витрат на одиницю корисності, тому менше його значення отримує перевагу при порівнянні методик лікування.

У роботі використано розрахунок вартості наданих послуг хворим на ВХШ в умовах стандартного хірургічного стаціонару ТМКЛ № 2. Оплата праці та вартість витратних матеріалів проведені із розрахунку станом на I півріччя 2015 року. При розрахунку вартості медикаментозного забезпечення використано середньорозрахункову роздрібну ціну на лікарські препарати, наведені у щотижневику “Аптека”, станом на серпень 2015 р. Витрати, пов’язані рівною мірою з консервативним та операційним лікуванням, обчислювати не вважали за доцільне.
Результати досліджень та їх обговорення. Проведено віковий розподіл та статеву належність всіх хворих згідно з рекомендаціями ВООЗ, що представлено в таблиці 1.

Звертає на себе увагу наявність цієї патології в більшості осіб працездатного віку від 20 до 59 років (49 \%), що вказує на соціальне значення даної проблеми.

За період дослідження було проведено 111 операційних втручань, 3 них 47 органощадних за запропонованими нами методиками, 57 пацієнтів отримали консервативне лікування. ЯЖ пацієнтів, за результатами анкетування, представлено в таблиці 2.

До прямих медичних витрат враховано кількість медперсоналу, задіяного в операції залежно від виду операції, та оплату його праці, витратні матеріали при виконанні операцій, середні витрати на перев’язки у післяопераційному періоді, середню вартість післяопераційного медикаментозного забезпечення (табл. 3).

Тривалість курсу лікування згідно з протоколом надання медичної допомоги хворим на неускладнену ВХШ та інші пептичні виразки шлунка та/або дванадцятипалої кишки складає 4 тижні (28 днів) [7]. При розрахунку вартості курсу антигелікобактерної терапії пептичної виразки шлунка, асоційованої з H. pylori, досліджуваними схемами враховували тільки витрати на лікарські препарати (табл. 4).

Для обчислення показника QALY враховували тривалість подовженого життя хворих після досліджуваних методів лікування. Середній вік пацієнтів складав 55,4 року. Для України в 2012 році середня тривалість життя складала 71 рік [8]. Виходячи з цього, хворі можуть прожити в середньому ще 15,6 року.

Резекційні методи операційного лікування вимагають додаткового лікування чи навіть повтор-

Таблиця 1. Розподіл хворих за віком і статтю

\begin{tabular}{|c|c|c|c|c|c|c|c|c|}
\hline \multirow{3}{*}{ Стать } & \multicolumn{8}{|c|}{ Вік, роки } \\
\hline & \multicolumn{2}{|c|}{$20-59$} & \multicolumn{2}{|c|}{$60-74$} & \multicolumn{2}{|c|}{ 75-89 } & \multicolumn{2}{|c|}{ Всього } \\
\hline & абс. & $\%$ & абс. & $\%$ & абс. & $\%$ & абс. & $\%$ \\
\hline Чоловіки & 56 & 33 & 54 & 32 & 7 & 5 & 117 & 70 \\
\hline Жінки & 27 & 16 & 22 & 13 & 2 & 1 & 51 & 30 \\
\hline Всього & 83 & 49 & 76 & 45 & 9 & 6 & 168 & 100 \\
\hline
\end{tabular}

Таблиця 2. Якість життя пацієнтів після різних методів лікування

\begin{tabular}{|l|c|c|}
\hline \multicolumn{1}{|c|}{ Метод лікування } & Проліковано пацієнтів & Якість життя \\
\hline Резекційні операційні втручання & 64 & 76,3 \\
\hline Органощадні операційні втручання & 47 & 91,5 \\
\hline Консервативне лікування & 57 & 84,6 \\
\hline
\end{tabular}


Таблиця 3. Сумарна вартість операційного лікування хворих на ВХШ

\begin{tabular}{|l|c||}
\hline \multicolumn{1}{|c|}{ Показник } & Вартість, грн \\
\hline Оплата праці операційної бригади & 347,48 \\
\hline Оплата праці анестезіологічної бригади & 195,21 \\
\hline Витратні матеріали при виконанні операцій & 1503,25 \\
\hline Середні витрати на перев’язки у післяопераційному періоді & 108,90 \\
\hline Середня вартість післяопераційного медикаментозного забезпечення & 3460,56 \\
\hline Всього & 5615,4 \\
\hline
\end{tabular}

Таблиця 4. Витрати на лікарські препарати, які входять до складу схеми послідовної терапії виразкової хвороби

\begin{tabular}{|c|c|c|c|c|c|}
\hline МНН препарату & $\begin{array}{c}\text { Торгова назва } \\
\text { препарату }\end{array}$ & Дозування & $\begin{array}{c}\text { Форма } \\
\text { випуску }\end{array}$ & $\begin{array}{c}\text { Витрати на ЛП } \\
\text { на курс терапії, грн }\end{array}$ & $\begin{array}{c}\text { Вартість } \\
\text { схеми, грн }\end{array}$ \\
\hline \multicolumn{5}{|l|}{ Перша фаза (5 днів) } & \multirow{9}{*}{2601,71} \\
\hline Рабепразол & Парієт $^{\circledR}$ & 1 таб. 2 р/д & $\begin{array}{c}\text { Таб. } 20 \text { мг } \\
\text { № } 14 \\
\end{array}$ & 373,1 & \\
\hline Амоксицилін & $\begin{array}{c}\text { Флемоксин } \\
\text { Солютаб }^{\circledR}\end{array}$ & 1 таб. 2 р/д & $\begin{array}{c}\text { Таб. } 1000 \text { мг } \\
\text { № } 20 \\
\end{array}$ & 84,79 & \\
\hline \multicolumn{5}{|l|}{ Друга фаза (5 днів) } & \\
\hline Рабепразол & Парієт $^{\circledR}$ & 1 таб. 2 р/д & $\begin{array}{c}\text { Таб. } 20 \text { мг } \\
\text { № } 14 \\
\end{array}$ & 373,1 & \\
\hline Кларитроміцин & Клацид СР & 1 таб. 2 р/д & $\begin{array}{c}\text { Таб. } 500 \text { мг } \\
\text { № } 5\end{array}$ & 732,08 & \\
\hline Препарат вісмуту & Де-Нол ${ }^{\circledR}$ & 2 таб. 2 р/д & $\begin{array}{c}\text { Таб. } 120 \text { мг } \\
\text { № } 112\end{array}$ & 66,95 & \\
\hline \multicolumn{5}{|c|}{ Прийом антисекреторного препарату наступні 18 днів } & \\
\hline Рабепразол & Парієт $^{\circledR}$ & 1 таб. 2 р/д & $\begin{array}{c}\text { Таб. } 20 \text { мг } \\
\text { № } 14\end{array}$ & 971,69 & \\
\hline
\end{tabular}

ного операційного втручання у 50 \% випадків [9]. Тому тривалість подовженого життя для хворих після резекційних методів операційного лікування становить 15,6 року · 50 \%/100 \%=7,8 року. QALY розраховується як добуток показника ЯЖ і подовжених років після лікування. Для хворих після резекційних методів операційного лікування QALY розраховано:

QALY=76,3·7,8=595,14.

Враховуючи дані, що у 4,5 \% пацієнтів після органозберігаючого методу операційного лікування виникають післяопераційні функціональні розлади, що потребують медикаментозної корекції, тривалість подовженого життя для цих хворих становить 15,6 року $\cdot 95,5 \% / 100 \%=14,9$ року.

QALY=91,5·14,9=1363,35.

Оскільки, за даними наших досліджень, середня частота загострень виразки - 7,8 раза протягом 5 років, то середня тривалість відсутності терапії для пацієнтів, які отримували консервативне лікування, склала 0,64 року.

QAL Y=84,6•0,64=54,14.

Узагальнений фармакоекономічний коефіцієнт “витрати-корисність», розраховували для досліджуваних методів лікування:

- резекційного - CUR=5615,4/595,14=9,44;

- органощадного - CUR=5615,4/1363,35=4,12;

- консервативного - CUR=2601,71/54,14=48,05.

Результати обчислень доводять, що оптимальним вибором лікування ВХШ з фармакоекономічної точки зору є органощадні операційні втручання.

Висновки. 1. Проведено порівняльну оцінку резекційних та органозберігаючих операційних втручань, а також консервативного лікування фармакоекономічним методом “витрати-корисність”.

2. Обгрунтовано переваги органощадних операційних втручань з фармакоекономічної точки зору. 


\section{СПИСОК ЛІТЕРАТУРИ}

1. Скрипник I. М. Епідеміологічні, патогенетичні, лікувальні та фармакоекономічні аспекти пептичної виразки, асоційованої з гастроезофагеальною рефлюксною хворобою, у військовослужбовців / І. М. Скрипник, Г. В. Осьодло // Сучасна гастроентерол. - 2011. - № 5. - С. 9-16.

2. Лупальцов В. И. Хирургическое лечение гастродуоденальных язв в соответствии с принципами современной противорецидивной терапии с предупреждением послеоперационных осложнений / В. И. Лупальцов, Ю. В. Артемов // Клінічна хірургія. - 2011. - № 1. - С. 9-12.

3. Мамчич В. І. Вибір способу оперативного лікування хворих із гігантською виразкою шлунка / В. І. Мамчич, О. В. Грузинський // Укр. мед. часопис. - 2011. - № 1 (81) - С. 101-104. 4. Pharmacoeconomics : from theory to practice / editor Renee J. G. Arnold // Drug Discovery Series: CRC Press, Taylor \& Francis Group. Boca Raton, London, New York. - 2010. - Chapter 8. - 243 p.
5. Доценко В. В. Перспективи дослідження якості життя хворих, прооперованих із приводу перфоративної гастродуоденальної виразки / В. В. Доценко // Харківська хірургічна школа. - 2013. - №4 (61). - С. 120-123.

6. McGregor M / Cost-utility analysis: use QALYs only with great caution / M. McGregor // Can. Med. Ass. J. - 2003. - Vol. 168. - Р. 433-434.

7. Україна. Наказ МОЗ від 13.06.2005 № 271 “Про затвердження протоколів надання медичної допомоги за спеціальністю “Гастроентерологія”.

8. http://gamapserver.who.int/gho/interactive charts/mbd/life expectancy/atlas.html

9. Трухалев В. А. Современное состояние проблемы лечения перфоративной язвы желудка и двенадцатиперстной кишки / В. А. Трухалев, Г. И. Гомозов // Современные проблемы науки и образования. - 2014. - № 2. - С. 293-305.

Отримано 15.07.15 